\title{
Humic-like substances in fresh emissions of rice straw burning and in ambient aerosols in the Pearl River Delta Region, China
}

\author{
P. Lin ${ }^{1}$, G. Engling ${ }^{2}$, and J. Z. Yu ${ }^{1,3,4}$ \\ ${ }^{1}$ Division of Environment, Hong Kong University of Science and Technology, Clear Water Bay, Kowloon, Hong Kong, China \\ ${ }^{2}$ Research Center for Environmental Changes, Academia Sinica, Taipei, Taiwan \\ ${ }^{3}$ Department of Chemistry, Hong Kong University of Science and Technology, Clear Water Bay, Kowloon, Hong Kong, China \\ ${ }^{4}$ Atmospheric Research Center, HKUST Fok Ying Tung Graduate School, Nansha, Guangzhou 511458, China
}

Received: 1 March 2010 - Published in Atmos. Chem. Phys. Discuss.: 17 March 2010

Revised: 8 July 2010 - Accepted: 9 July 2010 - Published: 16 July 2010

\begin{abstract}
HUmic-LIke Substances (HULIS) are an abundant unresolved mixture of organic compounds present in atmospheric samples. Biomass burning (BB) has been recognized as an important primary source of HULIS, but measurements of HULIS in various fresh BB particles are lacking. In this work, HULIS in emissions of rice straw burning was measured in a number of field and chamber experiments. The average HULIS/OC ratio was $0.34 \pm 0.05$ in $\mu \mathrm{g} / \mu \mathrm{gC}$, showing small variance among emissions under different burning conditions. The influence of BB on ambient HULIS levels was investigated by examining the spatial and temporal variation of HULIS and other aerosol constituents and interspecies relations in ambient $\mathrm{PM}_{2.5}$. The $\mathrm{PM}_{2.5}$ samples were collected at an urban and a suburban location in the Pearl River Delta (PRD), China over a period of one year. The HULIS concentrations in the ambient $\mathrm{PM}_{2.5}$ were significantly higher in air masses originating from regions influenced by BB. Significant correlations between HULIS and water-soluble $\mathrm{K}^{+}$concentrations at both sites further support that BB was an important source of HULIS. Ambient concentrations of HULIS also correlated well with those of sulfate, oxalate, and oxidant (the sum of $\mathrm{O}_{3}$ and $\mathrm{NO}_{2}$ ). The HULIS/OC ratios in BB-influenced ambient aerosols $(\sim 0.6)$ were much higher than those in the fresh BB emissions (0.34), implying that secondary formation was also an important source of HULIS in the atmosphere. The annual average HULIS concentrations were $4.9 \mu \mathrm{g} \mathrm{m}^{-3}$ at the urban
\end{abstract}

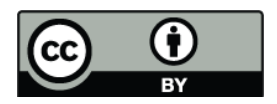

Correspondence to: J. Z. Yu (chjianyu@ust.hk) site and $7.1 \mu \mathrm{g} \mathrm{m}^{-3}$ at the suburban site while the annual average concentrations of elemental carbon were $3.3 \mu \mathrm{g} \mathrm{m}^{-3}$ and $2.4 \mu \mathrm{g} \mathrm{m}^{-3}$, respectively. The urban-suburban spatial gradient of HULIS was opposite to that of elemental carbon, negating vehicular exhaust as a significant primary emission source of HULIS.

\section{Introduction}

Humic-like substances (HULIS) are an unresolved mixture of water-extracted organic compounds from atmospheric aerosol particles or isolated from fog/cloud water samples. They are thought to be comprised of aromatic and aliphatic structures containing hydrophilic oxygenated functional groups such as hydroxyl, carboxyl, carbonyl, nitrate, and nitroxy organosulfate groups (Mukai and Ambe, 1986; Graber and Rudich, 2006; Reemtsma et al., 2006; Altieri et al., 2009a; Mazzoleni et al., 2010). Recent studies using ultrahigh-resolution Fourier Transform ion cyclotron resonance mass spectrometry have led progresses in identification of structural moieties and determination of chemical formula of individual compounds in HULIS (i.e., Wozniak et al., 2008; Altieri et al., 2009a, b; and Mazzoleni et al., 2010). However, complete molecular-level chemical characterization of the HULIS fraction remains unachieved. The name HULIS was derived from their considerable similarities in structural properties to terrestrial and aquatic humic and fulvic acids (e.g., Zappoli et al., 1999; Kiss et al., 2002; Sannigrahi et al., 2006; Duarte et al., 2007). Laboratory studies have shown that HULIS can be important in

Published by Copernicus Publications on behalf of the European Geosciences Union. 
the troposphere in issues such as hygroscopic growth and cloud condensation nuclei formation of aerosols (Dinar et al., 2006; Gysel et al., 2004), light extinction (Hoffer et al., 2006; Lukacs et al., 2007), atmospheric chemistry processes such as aqueous-phase oxidation of organic pollutants (Moonshine et al., 2008) and ozone depletion on aerosol surfaces (D'Anna et al., 2009).

Ambient concentrations of HULIS reported in the literature vary over more than three orders of magnitude, from $0.08 \mu \mathrm{g} \mathrm{m}^{-3}$ in a marine location (Krivácsy et al., 2008) to $28 \mu \mathrm{g} \mathrm{m}^{-3}$ in a rural location affected by forest fires (MayolBracero et al., 2002). HULIS represents a significant fraction of organic carbon mass and water-soluble organic carbon (WSOC). For example, Fermo et al. (2009) reported that HULIS represented over $50 \%$ of organic carbon mass in urban aerosols of Italy. In studies where both HULIS and WSOC were measured, HULIS was found to account for 9-72\% of WSOC (e.g., Kiss et al., 2002 and Feczko et al., 2007).

Biomass burning (BB) is one of the major global sources of atmospheric particles. A number of field studies have provided evidence that $B B$ is also a significant source of HULIS (Mukai and Ambe, 1986; Mayol-Bracero et al., 2002; Samburova et al., 2005; Lukacs et al., 2007; Feczko et al., 2007; Lin et al., 2010). However, direct measurements of HULIS in fresh BB emissions are still lacking. In this study, we have measured HULIS abundance in fresh emissions from rice straw burning conducted both in the field and in a laboratory chamber. Rice straw burning has been chosen mainly because rice is the dominant crop in our study region, the Pearl River Delta (PRD) in South China.

BB is an important aerosol source in South China (Yuan et al., 2006; Zheng et al., 2006). Among the various types of BB in the Pearl River Delta (PRD), crop residue burning, rather than forest or grassland fire, is estimated to be the main form of open BB emissions (Streets et al., 2003). During and after the harvest season, farmers often burn crop residues in the field as a convenient and inexpensive way to dispose of agricultural waste and to advance crop rotation. In addition, crop residues are also used as cooking fuels in the rural areas throughout the year.

We previously collected a small set of ambient aerosol samples at a rural location in the PRD at a time with a visible presence of crop residue burning. Our measurements showed that HULIS was abundant in these samples, ranging from 5.9 to $18.1 \mu \mathrm{g} \mathrm{m}^{-3}$ (Lin et al., 2010). However, no measurements of HULIS in the urban and suburban areas of the PRD have been conducted to date. Therefore, abundance of HULIS and contributions of BB to HULIS in these atmospheric environments remain unknown. In this study, the HULIS concentrations, along with other major aerosol constituents, were determined in ambient aerosols sampled at an urban and a suburban site over a one-year period from July 2007 to June 2008 following a one-in-six day sampling schedule. One objective was to determine abundance, as well as temporal and spatial variation of HULIS in this region. Results derived from the small set of measurements in our previous study (Lin et al., 2010) also suggest that secondary formation and primary emissions from biomass burning are important sources of HULIS in rural areas in the PRD region. The second objective of the current study was to assess the contribution of primary BB emissions to ambient HULIS in the region and to examine whether there is evidence indicating secondary formation of HULIS is promoted by BB particles or gaseous components in BB emissions.

\section{Experimental section}

\subsection{Biomass burning source aerosol sampling}

Fresh BB emissions samples were collected in a series of field burning experiments conducted in the PRD and Taiwan, as well as in laboratory burning experiments. In the PRD, open burning of rice straw and sugarcane leaves were conducted in a small village in rural PRD in November 2007. Rice straw in small bundles and sugarcane leaves in thin piles were burned, simulating their burning processes in the field as practiced by local farmers. $\mathrm{PM}_{2.5}$ smoke particles were collected about $5 \mathrm{~m}$ downwind of the fires. Details of this experiment have been reported in our previous publication (Lin et al., 2010). In Taiwan, the rice straw burning experiment was conducted in a rural part of Yunlin Country in February 2007 at the end of the winter burning season of rice fields. Rice straw was placed in the field in thin layers and burned slowly, resembling typical conditions for rice straw burning in Taiwan. $\mathrm{PM}_{2.5}$ samples were collected approximately $30 \mathrm{~m}$ downwind of the fire on the rooftop of a two-story building (Engling et al., 2009).

Controlled BB experiments were conducted in the combustion chamber of the U.S. Forest Service Fire Science Lab (FSL, Missoula, MT, USA). Smoke aerosol samples $\left(\mathrm{PM}_{2.5}\right)$ were collected from eight rice straw burns (including one controlled flaming burn, one controlled smoldering burn and six mixed phase burns), one charcoal burn and one sugarcane burn and analyzed for HULIS. Details about these chamber combustion experiments have been reported by McMeeking et al. (2009).

\subsection{Ambient aerosol sampling}

Ambient aerosol samples were collected at an urban and a suburban location in the PRD. The urban location was Tsuen Wan (TW, $22^{\circ} 22^{\prime} 18.14^{\prime \prime} \mathrm{N}, 114^{\circ} 06^{\prime} 52.42^{\prime \prime} \mathrm{E}$ ) in Hong Kong, which is also an air quality monitoring site of the Hong Kong Environmental Protection Department (HKEPD). The TW site is $\sim 0.8 \mathrm{~km}$ from the coastline. The Nansha (NS, $22^{\circ} 45^{\prime} 08.90^{\prime \prime} \mathrm{N}, 113^{\circ} 36^{\prime} 09.17^{\prime \prime} \mathrm{E}$ ) site is in the suburban area of Guangzhou, at the mouth of the Pearl River in the middle of the PRD. NS is $\sim 70 \mathrm{~km}$ northwest of TW and 
$\sim 50 \mathrm{~km}$ southwest to Guangzhou urban center. Once every 6 days, 24-h $\mathrm{PM}_{2.5}$ sampling was conducted at TW and NS from July 2007 to August 2008. The $\mathrm{PM}_{2.5}$ samples were collected using a 4-channel mid-volume sampler (RAAS 400, Thermo Andersen, USA). RAAS collects fine particles onto filters via two separate flows of $24 \mathrm{~L} \mathrm{~min}^{-1}$. Each flow passes through a $\mathrm{PM}_{2.5}$ cyclone and subsequently splits into two flow lines, one at $16.7 \mathrm{~L} \mathrm{~min}^{-1}$ and the other at $7.3 \mathrm{~L} \mathrm{~min}^{-1}$. The four sampling channels were loaded with a Teflon filter, a Nylon filter with sodium carbonate coated denuder placed upstream, and two quartz fibre filters. The Teflon filters were used for determination of $\mathrm{PM}_{2.5}$ mass concentrations; the Nylon filters were used for watersoluble ions; and the quartz fibre filters were used for organic carbon (OC) and elemental carbon (EC) analysis. A high-volume aerosol sampler (TE-6070V-BL, Tisch Environmental Inc., USA) was also employed at each site to collect $\mathrm{PM}_{2.5}$ and $\mathrm{PM}_{2.5-10}$ samples on prebaked quartz filters concurrently with the mid-volume $\mathrm{PM}_{2.5}$ sampler. A portion of each $\mathrm{PM}_{2.5}$ high-volume filter was removed and processed for HULIS determination. $\mathrm{PM}_{2.5-10}$ filters were not analyzed for HULIS because our previous study indicated that more than $90 \%$ of HULIS in ambient aerosols in this region reside in fine particles (Lin et al., 2010) and those coarsemode samples have been reserved for other analyses.

\subsection{Chemical analysis}

HULIS is operationally defined by the isolation and detection protocol used for its determination. A number of methods, differing in either the isolation step or the detection means, have been reported for the determination of HULIS. The atmospheric community has not yet agreed on a standard analytical method for HULIS. Techniques applied to isolate HULIS from bulk aerosol materials include solid phase extraction (e.g., Varga et al., 2001), ultrafiltration (e.g., Havers et al., 1998a), capillary electrophoresis (e.g., Havers et al., 1998b), ion-exchange chromatography (e.g., Decesari et al., 2000), size-exclusion chromatography (e.g., Krivacsy et al., 2000; Samburova, et al., 2005), and reversed-phase chromatography (e.g. Hutta et al., 2003). Limbeck et al. (2005) developed a more complex two-step isolation procedure, the first step using polar interactions on a C-18 SPE cartridge and the second one utilizing the acidic nature of HULIS to isolate them on SAX resin, a strong anion exchanger. Quantification methods for HULIS include TOC analyzer (e.g., Krivacsy et al., 2000), UV-VIS detector (e.g., Samburova, et al., 2005), evaporative light scattering detector (ELSD) (e.g., Emmenegger et al., 2007), and gravimetric measurements (Salma et al., 2010). One recent study (Baduel et al., 2009) compared two HULIS determination procedures and found that a one-step DEAE (a weak anion exchanger) isolation procedure leads to higher recoveries and better reproducibility than Limbeck et al.'s two-step C18-SAX procedure. However, the high ionic strength used in the final elution step in the DEAE isolation procedure makes it difficult to characterize the chemical and physical properties of HULIS due to interferences with the abundant inorganic ions.

In this work, HULIS in aerosol filter samples was first isolated from the other constituents in water extracts using solid phase extraction (SPE), followed by quantification with ELSD. This method was adopted with modifications from the isolation procedure developed by Varga et al. (2001) and quantification using ELSD proposed by Emmenegger et al. (2007). Details on the characteristics and performance of this method have been reported in our previous work (Lin et al., 2010). In brief, portions $\left(3-30 \mathrm{~cm}^{2}\right)$ of the highvolume filters were extracted with water in an ultrasonic bath. The ratio of filter sample area to water volume was about $1 \mathrm{~cm}^{2} \mathrm{~mL}^{-1}$. The extract was acidified to $\mathrm{pH} 2 \mathrm{using}$ $\mathrm{HCl}$ before it was loaded on a SPE cartridge (Oasis HLB, $30 \mu \mathrm{m}, 60 \mathrm{mg} / \mathrm{cartridge}$, Waters, USA). By this SPE separation procedure, compounds bearing aromatic rings and multiple polar functional groups that are protonated at $\mathrm{pH} 2$ are retained on the SPE sorbent, while the strongly hydrophilic substances such as inorganic ions, low molecular weight organic acids and sugar compounds (e.g., levoglucosan, xylose and sucrose) pass through the SPE cartridge and appear in the effluent fraction. The loaded cartridge was subsequently rinsed with two $1 \mathrm{~mL}$ portions of water before elution with three portions of $0.5 \mathrm{~mL}$ methanol containing $2 \%(w / w)$ ammonia. The eluate was collected and evaporated to dryness at $90^{\circ} \mathrm{C}$ under a gentle stream of $\mathrm{N}_{2}$ and re-dissolved in $1.0 \mathrm{~mL}$ of water and then injected into an ELSD (Model 3300, Alltech, USA) for HULIS quantification. The detection limit of this method was $7 \mathrm{ng} \mu \mathrm{L}^{-1}$ and the recovery of HULIS was estimated to be $\sim 90 \%$ by using SRFA (Suwannee River Fulvic Acid) and NAFA (Nordic Aqueous Fulvic Acid) reference standards (Lin et al., 2010).

$\mathrm{OC}$ and $\mathrm{EC}$ in $\mathrm{PM}_{2.5}$ samples were measured using a Sunset OC/EC analyzer (Sunset Laboratory, Tigard, OR, USA) based on a thermal/optical transmittance (TOT) method. Ionic species were determined using an ion chromatography (IC) system (DX500, Dionex, Sunnyvale, CA, USA). The anions $\left(\mathrm{Cl}^{-}, \mathrm{NO}_{3}^{-}, \mathrm{SO}_{4}^{2-}\right.$, and oxalate) were separated on an AS-11 column by gradient elution with a $\mathrm{NaOH}$ solution. The cations $\left(\mathrm{Na}^{+}, \mathrm{NH}_{4}^{+}, \mathrm{K}^{+}, \mathrm{Mg}^{2+}\right.$, and $\left.\mathrm{Ca}^{2+}\right)$ were separated on a CS-12 column with an isocratic eluent solution of methanesulfonic acid. The details of the OC/EC and IC measurement methods were described in previous reports by our group (Yang et al., 2005; Lin et al., 2010).

\section{Results and discussion}

\subsection{HULIS emissions from biomass burning processes}

The emissions of HULIS and $\mathrm{K}^{+}$from different rice straw burning experiments were normalized against $\mathrm{OC}$, mainly on the consideration that $\mathrm{OC}$ was the most abundant constituent 
in BB particles. The $\mathrm{K}^{+} / \mathrm{OC}$ and HULIS/OC ratios in emissions from the different chamber and field burning experiments are plotted in Fig. 1. Among different burning experiments, the $\mathrm{K}^{+} / \mathrm{OC}$ values were rather variable, ranging from 0.06 to 0.38 , whereas the HULIS/OC ratios had less variation, ranging from 0.26 to 0.44 and with an average of 0.34 and a standard variation of 0.05 . The HULIS/OC ratios in the chamber-generated $\mathrm{BB}$ smoke were in the range of 0.28-0.44. It is noted that in the chamber studies fresh rice straw emissions did not include substantial dilution, thus the OC concentrations may be biased higher and thereby the HULIS/OC may be biased lower due to presence of semivolatile compounds on the freshly emitted particles.

Potassium ion is an essential plant nutrient and can be found in most soil types. Potassium salts such as $\mathrm{KCl}$, $\mathrm{K}_{2} \mathrm{SO}_{4}$ and $\mathrm{KNO}_{3}$ are also widely used as fertilizers. Consequently, $\mathrm{K}^{+}$is one of the most enriched elements in plants and is usually abundant in aerosols emitted from combusted plants (e.g., Allen and Miguel, 1995; Lin et al., 2010). The combustion process and particle formation during biomass burning are highly complex processes including many physical transformations and chemical reactions (Simoneit et al., 2002). The emission factors of particulate organic compounds from burning of a given type of biomass typically vary with combustion conditions (Andreae and Merlet, 2001). Likewise, $\mathrm{K}^{+}$emissions are affected by the fire temperature and the phase of burning processes (i.e., smoldering and flaming burns) (e.g., Echalar et al., 1995; Khalil and Rasmussen, 2003). Higher fire temperatures favor the volatilization of potassium salts (e.g., $\mathrm{KCl}$ with a boiling point of $1420^{\circ} \mathrm{C}$ ). The variation in the ratio of $\mathrm{K}^{+} / \mathrm{OC}$ in $\mathrm{BB}$ particles during different experiments of rice straw burning could therefore more or less reflect the variation in burning conditions as well as in the growing locations of the rice straw. For example, the $\mathrm{K}^{+} / \mathrm{OC}$ ratio was higher in the $\mathrm{BB}$ particles from a flaming burn than from a smoldering burn in the chamber experiments. On the other hand, the fairly consistent HULIS/OC ratios suggested that the relative emission factors of HULIS to OC seem to be less dependent on the burning conditions.

In addition to burning of rice straw, fresh emission samples were also obtained from burning of two more biomass species, sugarcane leaves and charcoal, and analyzed for $\mathrm{K}^{+}$, HULIS, and OC. The HULIS/OC ratio was 0.28 in the burning emissions of sugarcane leaves and 0.32 in the emissions of charcoal, both values similar to those determined in various rice straw burning experiments (Table 1). Multiple samples were obtained from several sugarcane field burning experiments, allowing a comparison of variations in HULIS/OC and in $\mathrm{K}^{+} / \mathrm{OC}$ in different samples of sugarcane burning emissions. The coefficient of variation of $\mathrm{K}^{+} / \mathrm{OC}$ was $36 \%$, substantially larger than that of HULIS/OC (11\%).

The mechanisms of HULIS formation during the combustion processes are not fully understood yet. Biopolymers such as cellulose, lignin and lignans constitute the ma-

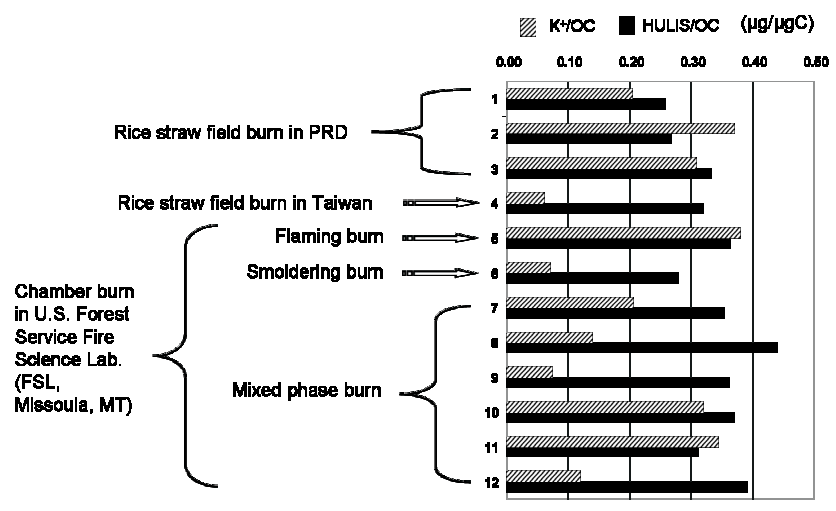

Fig. 1. HULIS and $\mathrm{K}^{+}$emissions normalized by OC concentrations in different rice straw burning samples. The OC data were determined by the TOT method except those from rice straw field burn in Taiwan (No. 4), which were obtained by the TOR (thermal/optical reflectance) method.

jor fraction of organic matter in biomass (Simoneit et al., 2002). It is possible that HULIS is generated from the chemical transformations and thermal breakdown of plant lignin and cellulose during the combustion process (MayolBracero et al., 2002). In addition, during the combustion, certain semi-volatile and volatile organic compounds are expelled from the fuel due to the high temperatures of the fire (e.g., Lemieux et al., 2004; Hays et al., 2005). These gasphase compounds may also be oxidized at high temperatures to form carboxylate groups. As the plume cools down in the ambient air, organic compounds with higher molecular weight may be formed via recombination and condensation reactions between these lower molecular weight combustion products, thereby contributing to the HULIS fraction (Mayol-Bracero et al., 2002).

\subsection{HULIS in BB-affected ambient samples}

The origin and transport routes of air masses arriving at the urban and suburban sites on individual sampling days were examined using back trajectory analysis to identify the sampling days influenced by air masses passing BB source regions. The sampled air masses could be broadly divided into three major groups, that is, marine (Mar.), continental (Con.), and transition (Tra.) air masses, according to whether their routes traveled over the continent or South China Sea or inbetween, as shown in Fig. 3. Marine air masses influencing the sampling sites were mainly observed in summer while continental air masses were mainly found in winter and transition air masses occurred in spring and fall. Such seasonality in air mass origins influencing the PRD region agreed well with the seasonality of monsoon winds and was also consistent with back trajectory analyses from a previous study conducted by our group (Yu et al., 2004b). 
Table 1. HULIS/OC and $\mathrm{K}^{+} / \mathrm{OC}$ values in fresh biomass burning emissions and in different groups of ambient samples.

\begin{tabular}{lrrr}
\hline Samples & HULIS/OC $(\mu \mathrm{g} / \mu \mathrm{gC})$ & $\mathrm{K}^{+} / \mathrm{OC}(\mu \mathrm{g} / \mu \mathrm{gC})$ & $n$ \\
\hline $\begin{array}{l}\text { Fresh rice straw burning (field and } \\
\text { chamber burns) }\end{array}$ & $0.34 \pm 0.05$ & $0.22 \pm 0.12$ & 12 \\
$\begin{array}{l}\text { Fresh sugarcane leaves burning (field } \\
\text { burn) }\end{array}$ & $0.28 \pm 0.03$ & $0.45 \pm 0.16$ & 3 \\
$\begin{array}{l}\text { Fresh charcoal burning (chamber burn) } \\
\text { Rural ambient samples influenced by }\end{array}$ & $0.56 \pm 0.07$ & $0.11 \pm 0.02$ & 5 \\
$\begin{array}{l}\text { local biomass burning } \\
\text { Suburban ambient samples influenced } \\
\text { by biomass burning }\end{array}$ & $0.62 \pm 0.16$ & $0.077 \pm 0.027$ & 20 \\
$\begin{array}{l}\text { Urban ambient samples influenced by } \\
\text { biomass burning }\end{array}$ & $0.61 \pm 0.10$ & $0.084 \pm 0.023$ & 18 \\
$\begin{array}{l}\text { Mountain-top ambient samples affected } \\
\text { by long-range transport of biomass } \\
\text { burning emissions }\end{array}$ & $0.99 \pm 0.17$ & Not available & 3 \\
$\begin{array}{l}\text { Suburban ambient samples with mini- } \\
\text { mum biomass burning influence }\end{array}$ & $0.29 \pm 0.10$ & $0.050 \pm 0.033$ & 21 \\
$\begin{array}{l}\text { Urban ambient samples with minimum } \\
\text { biomass burning influence }\end{array}$ & $0.21 \pm 0.09$ & $0.045 \pm 0.040$ & 14 \\
\hline
\end{tabular}

When the sampled air masses had passed over the continental area of Mainland China, which is north to our sampling sites and is the BB source region, in the past $96 \mathrm{~h}$ before their collection at TW and NS, the samples were considered to be BB-influenced samples. In South China, BB takes place in the form of crop residue burning or cooking fuel burning in the countryside year around. On the other hand, ambient samples taken on days influenced by marine air masses from South China Sea are regarded to have minimum influence from BB emissions. All the marine air mass-influenced samples were obtained in the period from April to early September, during which more than $75 \%$ of annual precipitation in the PRD region occurred. The abundant rainfall helped to control hill fires and other accidental BB activities and also effectively removed BB particles together with other particulate matter by wet deposition. We next present BB tracer data to support the classification of the continental air masses as being BB-influenced.

Both levoglucosan and $\mathrm{K}^{+}$are known tracers for $\mathrm{BB}$ aerosols. In comparison, levoglucosan is a more robust $\mathrm{BB}$ tracer compound than $\mathrm{K}^{+}$. Almost all of the biomass activities emit levoglucosan but only burning of certain biomass emit $\mathrm{K}^{+}$while others such as wood burning emit little $\mathrm{K}^{+}$. For the samples reported in this study, $\mathrm{K}^{+}$data is available but levoglucosan has not been determined. We next examine aerosol chemical composition data for ambient $\mathrm{PM}_{2.5}$ samples from Hong Kong collected previously by our group to show that both levoglucosan and $\mathrm{K}^{+}$are good tracers for biomass burning in our study region.
In a chemical composition dataset of 30 ambient $\mathrm{PM}_{2.5}$ samples collected in Hong Kong from August 2004 to May 2005 , both $\mathrm{K}^{+}$and levoglucosan measurements were made and reported in the paper by Wan and Yu (2007). In these samples, levoglucosan and $\mathrm{K}^{+}$concentrations were positively correlated $\left(R^{2}=0.56, n=30\right)$. Applying the same method as the one used in the current study, we classify the samples into three subgroups according to the air mass back trajectories for the given sampling days. Both the levoglucosan and $\mathrm{K}^{+}$concentrations were nearly 10 times lower in the samples influenced by the marine air masses than those samples under the influence of the continental air masses (Fig. S1 in supplementary information). These results suggest that both levoglucosan and $\mathrm{K}^{+}$are suitable tracers for biomass burning in our study region. This conclusion is also consistent with two facts: (1) BB activities in form of crop residue burning either on agricultural fields or in household cooking stoves are known to be prevalent in this region; (2) potash fertilizer is widely used in the rural areas of south China. In the year 2007, 989200 tons of potash fertilizer was consumed in Guangdong Province. On average, $31.4 \mathrm{~kg}$ potash fertilizer was applied per mu (1 $\mathrm{mu}=667 \mathrm{~m}^{2}$ ) of cultivated land (Guangdong statistical yearbook 2008, http://www.gdstats.gov.cn/tjnj/ml_e.htm). The $\mathrm{K}^{+}$content in $\mathrm{PM}_{2.5}$ collected from simulated field burning of rice straw and sugarcane leaves confirms the abundant presence of $\mathrm{K}^{+}$in emissions from burning crops grown in this region (Lin et al., 2010). $\mathrm{K}^{+}$accounted for $13 \pm 3 \%$ and $14 \pm 2 \%$ of $\mathrm{PM}_{2.5}$ mass in rice straw and sugarcane leave smoke aerosols $\left(\mathrm{PM}_{2.5}\right)$ (Lin et al., 2010). 
In the ambient samples reported in this study, the concentrations of $\mathrm{K}^{+}$in the continental air masses were $1.2 \pm 0.4 \mu \mathrm{g}$ $\mathrm{m}^{-3}$ at the urban site and $1.5 \pm 0.7 \mu \mathrm{g} \mathrm{m}^{-3}$ at the suburban site. In comparison, the $\mathrm{K}^{+}$concentrations in the marine air masses-influenced samples were both $0.2 \pm 0.2 \mu \mathrm{g} \mathrm{m}^{-3}$ at the urban and the suburban site, 5-6 times lower than those in the continental air masses. The average $\mathrm{K}^{+} / \mathrm{EC}$ ratios in the marine air masses-affected samples were only 0.08 and 0.17 at the urban and suburban site, respectively. In contrast, in the continental air masses, this ratio was substantially higher: 0.42 at the urban site and 0.54 at the suburban site. These results support the broad classification of the continental air masses as being BB-influenced and the marine air massesaffected samples having significantly reduced influence by BB.

In comparison with the fresh BB samples, the HULIS/OC ratios were substantially higher in the $\mathrm{BB}$-affected ambient samples, reaching $0.62 \pm 0.16(n=20)$ in the BB-affected suburban samples and $0.61 \pm 0.10(n=18)$ in the BB-affected urban samples. In our earlier study, the average HULIS/OC ratio was observed at a slightly lower yet similar value of $0.56 \pm 0.10(n=5)$ in five samples collected at a rural location in the PRD at a time with visible presence of BB (Lin et al., 2010). For comparison, during weak influence by BB emissions, the HULIS/OC ratios were $0.29 \pm 0.10(n=21)$ in the suburban samples and $0.21 \pm 0.09(n=14)$ in the urban samples.

In a few selected aerosol samples collected in Taiwan when a clear long-range transport event of BB smoke was observed, the HULIS/OC ratio was even higher $(0.99 \pm 0.17$, $n=3$ ). These samples were collected at Lulin Atmospheric Background Station (LABS), located on top of Lulin Mountain (2860 m a.s.1.) in central Taiwan. The high elevation of LABS assures that it frequently lies in the free troposphere and is generally free from local pollution (Wai et al., 2008). Thus, it is a suitable sampling site to study the properties of long-range transported aerosols. Each year during spring and particularly in March, extensive BB activities, especially burning of agricultural residues (e.g., rice straw), occur in Indochina and India (Nguyen et al., 1994). Satellites images of fire hotspots, provided by the European Space Agency (http://dup.esrin.esa.int/ionia/wfa/index.asp), confirm the extensive BB activities in Indochina in March, 2007. Under certain synoptic weather conditions, the biomass smoke plumes can be transported from Indochina to the Western Pacific region (Bey et al., 2001). High levoglucosan concentrations in these samples (unpublished data of G. Engling) confirmed their BB origins. The results of another study conducted in March 2008 at the same site also demonstrated that the ambient aerosols sampled at LABS were influenced by long range transport of BB plumes (Lee et al., 2009; Chi et al., 2010; Sheu et al., 2010).

The observation of higher HULIS/OC ratios in the BBinfluenced ambient aerosols compared to those in the fresh $\mathrm{BB}$ emissions is consistent with formation of HULIS when the $\mathrm{BB}$ smoke ages in the atmosphere. Subsequent to BB emissions, multiple pathways could be at work leading to secondary formation of HULIS. First, numerous semivolatile and volatile organic compounds (VOCs), such as methoxy phenols, substituted benzoic acids, alkanes, alkanoic and alkanedioic acids, are emitted along with particlephase species during biomass burning (e.g., Hays et al., 2005; Mazzoleni et al., 2007). Some semi-volatile VOCs originally present on freshly emitted BB particles could off-gas as the BB particles are diluted in the atmosphere. These species could undergo oxidation by various atmospheric oxidants to form HULIS as BB smoke plumes age. Second, nitrogen oxides, along with $\mathrm{CO}$ and VOCs, are also emitted during biomass burning, leading to enhanced formation of ozone and other photooxidants (e.g., Chan et al., 2001; Marion et al., 2001; Thompson et al., 2001; Mckeen et al., 2002). The elevated oxidant level could in turn speed up secondary formation of HULIS from both BB-derived VOCs and VOCs already in the atmosphere from other emission sources. An aircraft study (Gao et al., 2003; Hobbs et al., 2003) on the evolution of gases and particles in a BB plume showed that the species derived from primary emissions (e.g., isoprene, benzene) were consumed while secondary species (e.g., ozone, sulfate, nitrate, and several organic acids) increased significantly in the aging BB plume. Third, high molecular weight products could be formed via acid-catalyzed particle-phase reactions of atmospheric organic carbonyl species (Jang et al., 2002). Such reactions were demonstrated in smog chamber experiments to occur on soot particles emitted from diesel and wood burning (Jang et al., 2003). Furthermore, it was shown in a smog chamber study that the acidity produced by organic acids was sufficient to promote acid-catalyzed reactions (Kalberer et al., 2004). As BB plumes age and mix with other particles in the atmosphere, it is possible that HULIS may result from acidcatalyzed heterogeneous reactions on pre-existing BB particles or on non-BB acidic particles involving organic precursors from BB. Fourth, BB particles contain abundant watersoluble organic species and potassium ion and are therefore readily activated by water vapor in the atmosphere (Rogers et al., 1991). Consequently these hydrated aerosols can serve as cloud condensation nuclei $(\mathrm{CCN})$, providing both the reacting medium and organic precursors for subsequent aqueous-phase reactions. The aqueous-phase reactions of certain organic precursors, e.g., levoglucosan (Holmes and Petrucci, 2006, 2007), 3,5-dihyoxybenzoic acid (Gelencser et al., 2003), methylglyoxal (Altieri et al., 2008), could form HULIS via polymerization/oligomerization reactions.

In summary, secondary formation of HULIS involving BB particles or gaseous components in BB emissions is plausible and could explain the enhanced HULIS content in BBaffected ambient aerosol samples. Further efforts are needed to identify major precursors in $\mathrm{BB}$ emissions contributing to HULIS. 

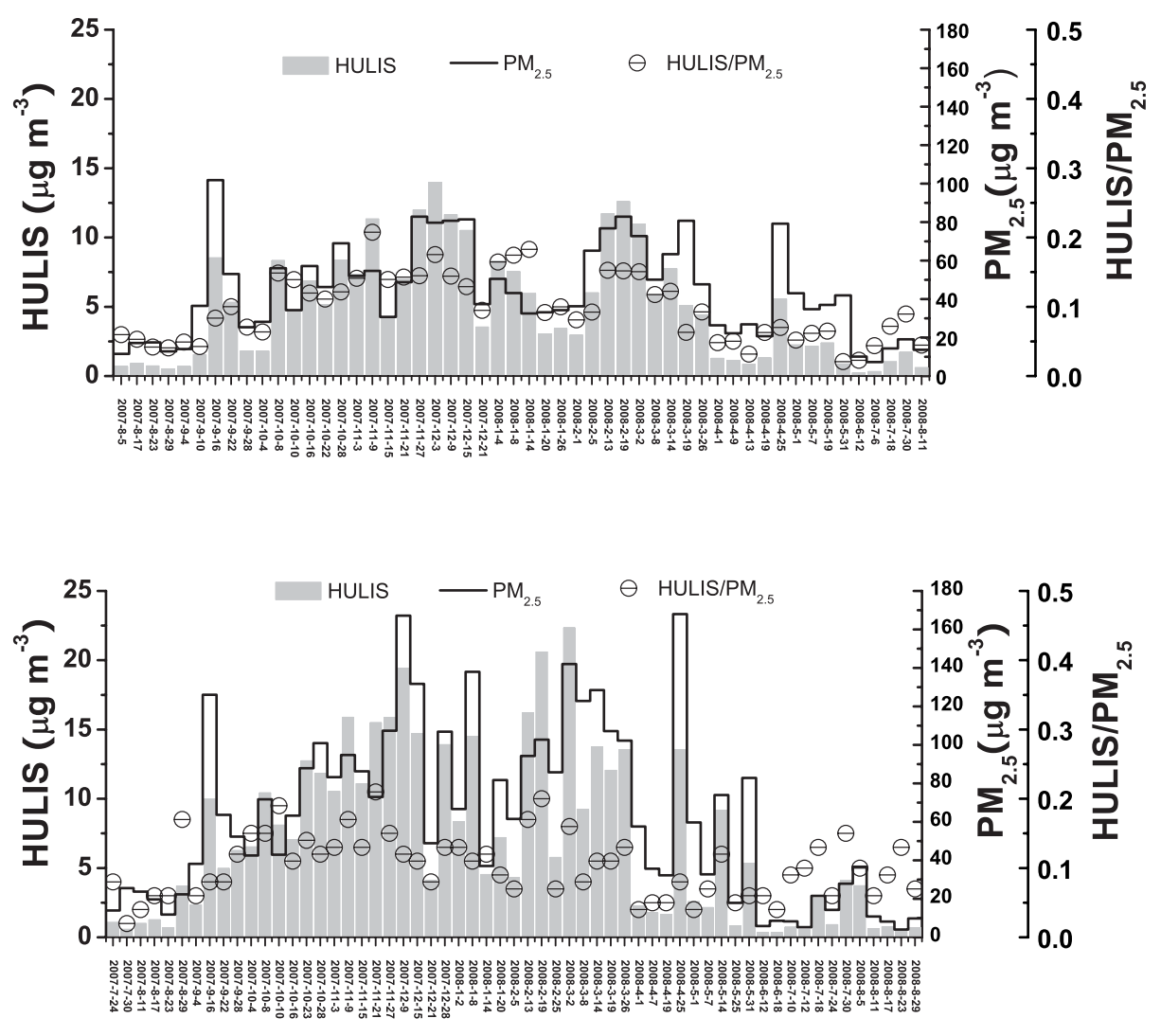

Fig. 2. Time series of HULIS, $\mathrm{PM}_{2.5}$ mass concentrations, and the relative abundance of HULIS in $\mathrm{PM}_{2.5}$ mass measured at the urban site (top) and suburban site (bottom).

\subsection{Temporal variations of HULIS at the urban and suburban sites}

The time series of one year HULIS and $\mathrm{PM}_{2.5}$ concentrations measured at the urban and suburban sites are shown in Fig. 2. At the urban site, the annual average concentration of HULIS was $4.9 \pm 3.9 \mu \mathrm{g} \mathrm{m}^{-3}$, accounting for $10 \pm 5 \%$ of the $\mathrm{PM}_{2.5}$ mass. At the suburban site, the annual average concentration of HULIS was $7.1 \pm 6.1 \mu \mathrm{g} \mathrm{m}^{-3}, 45 \%$ higher than that the urban site; however, its abundance in $\mathrm{PM}_{2.5}$ was $10 \pm 4 \%$, similar to that at the urban site. The annual average $\mathrm{PM}_{2.5}$ concentration at the suburban site was higher than that at the urban site, likely due to significantly higher concentrations of secondary inorganic species (e.g., sulfate, nitrate and ammonium). HULIS correlated significantly with $\mathrm{OC}$ at both the urban $(R=0.94)$ and the suburban site $(R=0.92)$. If a factor of 2.1 is used to estimate OM from OC (Chen and Yu, 2007), $26 \pm 12 \%$ of the particulate organic matter (POM) mass was comprised of HULIS at the urban site while the contribution was $22 \pm 9 \%$ at the suburban site. These results suggest that HULIS is an important class of POM in the ambient atmosphere of PRD.
Large temporal variations in HULIS concentrations were observed at both the urban and the suburban sites, with the maximum values more than 60 times higher than the minimum values. Lower HULIS concentrations mainly occurred in summer while higher HULIS concentrations were mainly found in winter. The highest HULIS concentration, $22.3 \mu \mathrm{g}$ $\mathrm{m}^{-3}$, was measured at the suburban site on 2 March 2008, when the 4-day air mass back-trajectories showed that air masses had passed over the continental area of Mainland China, residing approximately $24 \mathrm{~h}$ in the PRD region prior to being sampled at the suburban site (Fig. 3a). The lowest HULIS concentration, $0.23 \mu \mathrm{g} \mathrm{m}^{-3}$, was measured at the urban site on 12 June 2008 when the 4-day air masses had passed over the South China Sea (Fig. 3c). On the same day, the HULIS concentration at the suburban site was $0.33 \mu \mathrm{g}$ $\mathrm{m}^{-3}$, which was the lowest level measured at this site.

Figrue 4 shows the average concentrations of HULIS and other major aerosol constituents in the three air mass groups. HULIS concentrations displayed clear variation among the different groups at both the urban and the suburban sites. The average concentration of HULIS was nearly 10 times higher in the continental air masses than that in the marine air masses. At the urban site, the HULIS concentrations were $0.92 \pm 0.52 \mu \mathrm{g} \mathrm{m}^{-3}$ in the marine air masses versus 


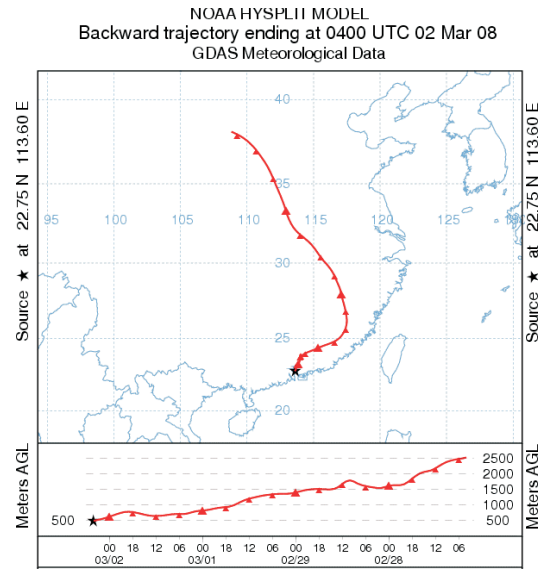

(a)

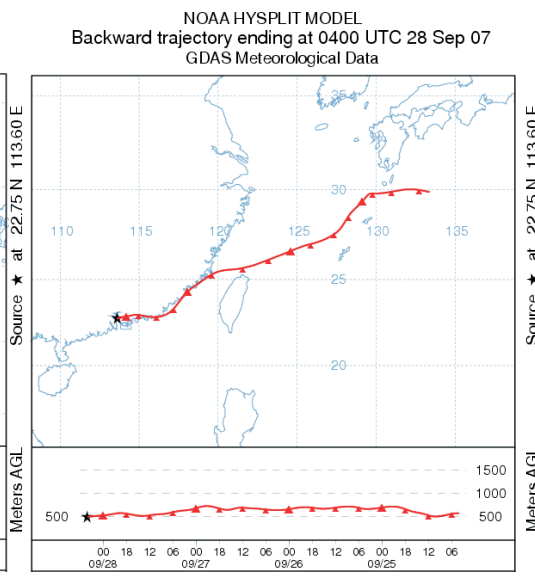

(b)

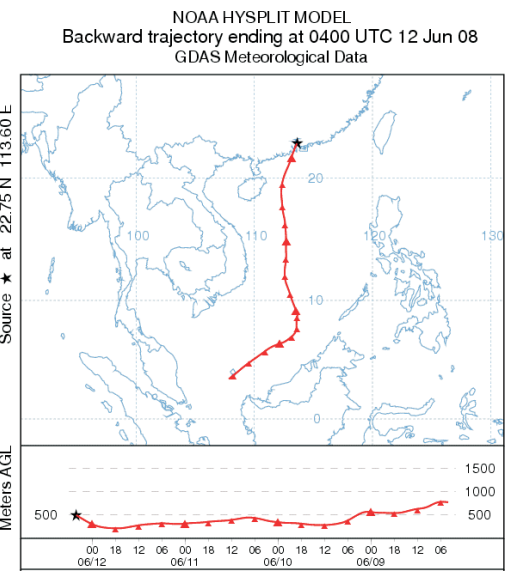

(c)

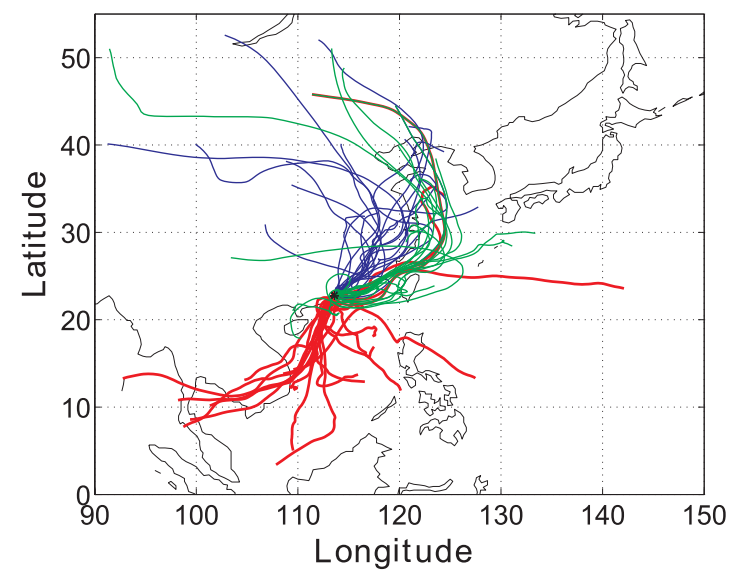

(d)

Fig. 3. Three examples of typical 96-h air mass back trajectories representing three types of air mass origin: (a) continental, (b) transition, and (c) marine. Panel (d) shows air mass trajectories of all the sampling days, with lines in blue, red, and green denoting air mass trajectories of continental, marine, and transitional origins, respectively.

$8.8 \pm 3.0 \mu \mathrm{g} \mathrm{m}^{-3}$ in the continental air masses. At the suburban site, these two values were $1.2 \pm 0.9$ and $12.7 \pm 5.2 \mu \mathrm{g}$ $\mathrm{m}^{-3}$, respectively. Under the influence of the continental air masses, HULIS accounted for $13.8 \pm 3.5 \%$ and $13.5 \pm 4.0 \%$ of the $\mathrm{PM}_{2.5}$ mass at the urban and suburban sites, respectively; while under the influence of the marine air masses, the relative HULIS abundance decreased to $5.2 \pm 1.7 \%$ and $7.3 \pm 3.4 \%$, respectively. These observations strongly indicated that the continental areas are dominant source regions for primary HULIS emissions and/or precursors of secondary HULIS. Our results agree with the findings of the study by Feczko et al. (2007), in which HULIS in samples from six background sites in Europe was determined.

The variation pattern of EC at the urban site within the three air mass groups was distinctly different from that of HULIS. Regardless of their air mass origins, the EC con- centrations in the three groups (marine, continental, and transition) were similar, with the concentrations at $3.4 \pm 1.1$, $3.0 \pm 1.0$, and $3.4 \pm 1.8 \mu \mathrm{g} \mathrm{m}^{-3}$, respectively. These observations indicate that EC at the urban site was largely locally emitted, which is consistent with the findings on EC sources in Hong Kong from previous field measurement studies (e.g., Yu et al., 2004a; Yuan et al., 2006; Hagler et al., 2006). Source apportionment using positive matrix factorization (PMF) analysis of $\mathrm{PM}_{10}$ chemical composition data indicates that EC in Hong Kong is mainly from vehicular emissions (Yuan et al., 2006). Other field measurements in Hong Kong also support this conclusion (e.g., Hagler et al., 2006). Ship emissions make somewhat important contributions to EC to the degree of accounting for the weak and variable seasonality of EC among different air quality monitoring stations in Hong Kong (Yu et al., 2004a). Contributions 
from other combustion sources (e.g., biomass burning, coal combustion, cooking) are minor to ambient EC loadings in Hong Kong. During periods with marine influence, EC accounted for more than $20 \%$ of $\mathrm{PM}_{2.5}$ mass, suggesting that vehicle exhaust, and perhaps ship emissions as well, is a major source of $\mathrm{PM}_{2.5}$ at the urban site when marine air masses prevail.

Nitrogen oxides and ozone data at TW are available from the HKEPD's air quality monitoring program. The measurement details of these criteria air pollutants are described in HKEPD's annual air quality reports (e.g., HKEPD, Air Quality in Hong Kong 2008, available at http://www.epd-asg.gov. hk/english/report/files/aqr08e.pdf). The nitrogen oxide (NO) data at TW were found to support the suggestion that EC at TW was mainly of local origin. NO is primarily from vehicular emissions at urban locations, such as TW. NO was positively correlated with EC at the urban site $\left(R^{2}=0.36, n=52\right)$. Daily average NO concentrations were of similar magnitude among air masses of the three categories, with slightly lower values in the continental group (Fig. 4a). Regional ozone transport was likely responsible for the depletion of NO in the continental air masses at the urban site. In comparison, variations in $\mathrm{O}_{3}$ and $\left(\mathrm{O}_{3}+\mathrm{NO}_{2}\right)$ concentrations among the three air mass groups reflect the secondary nature of these species and the prominent influence of regional/long-range transport on these species (Fig. 4a). The $\mathrm{O}_{3}$ and $\left(\mathrm{O}_{3}+\mathrm{NO}_{2}\right)$ concentrations in the continental air masses were more than twice those in the marine air masses. The low concentrations of HULIS as well as the low contributions of HULIS to $\mathrm{PM}_{2.5}$ in the samples influenced by marine air masses also implied that vehicular emissions and marine emissions (e.g., ship emissions) or sea salt aerosols are not important sources for HULIS in this region.

Variations in HULIS and EC at the suburban site among the three air mass groups were in agreement with the characteristics of the location and what we deduced from the TW data about known sources of HULIS and EC in the region. The suburban site is a receptor site downwind of Guangzhou during the winter (mostly in the case of continental air masses-affected samples) while downwind of Hong Kong during the summer (marine air masses-affected samples). Under the influences of marine air masses, aerosol was transported from the urban region of Hong Kong to NS, resulting in the high $\mathrm{EC}$ fractions in $\mathrm{PM}_{2.5}$ at NS. On the other hand, under the influences of continental air masses, air was mainly transported from Guangzhou and the northern part of the PRD region, leading to high PM concentrations and high levels of secondary inorganic ions. The HULIS concentrations and contributions to $\mathrm{PM}_{2.5}$ at NS displayed similar patterns among different air mass groups with those of the urban site (Fig. 4b). The low HULIS concentrations at the suburban site under influence of air masses transported from Hong Kong (i.e., marine air mass-influenced) support the statement that urban source emissions of Hong Kong were not important contributors of HULIS. (a) Urban site (Tsuen Wan, Hong Kong)
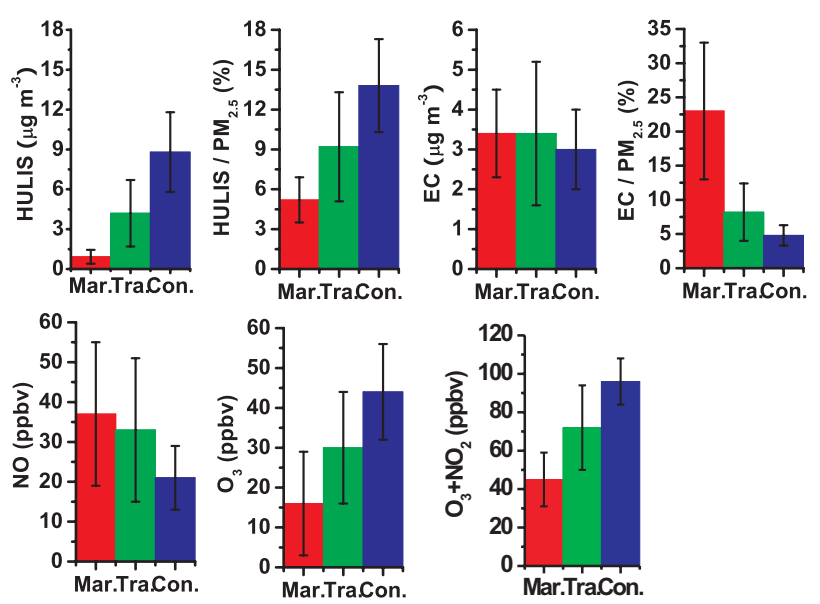

(b) Suburban site (Nansha, Guangzhou)
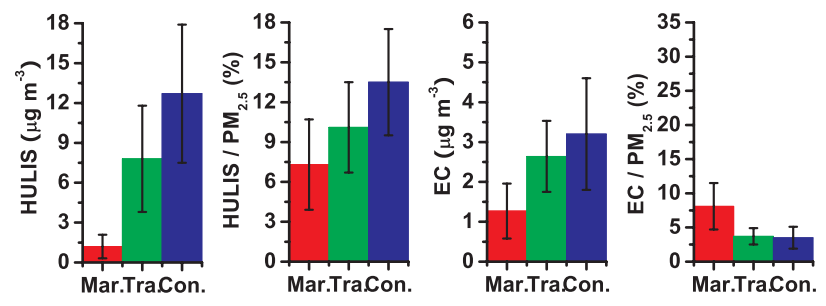

Fig. 4. Comparison of concentrations of selected particle-phase and gas-phase pollutants in three sample groups at (a) the urban site and (b) at the suburban site. The three groups are classified according to origins of the air masses influencing the sampling sites, with red, green, and blue denoting samples influenced by air masses of marine, transitional, and continental origins, respectively.

In summary, the temporal variations of HULIS in the PRD region were due to a combination of factors, including variation in source emissions and air mass transport to the sampling sites.

\subsection{Correlations between HULIS and other chemical species}

The correlation matrices between HULIS and other aerosol species at the urban and suburban sites are shown in Table 2. Good correlations between $\mathrm{K}^{+}$and HULIS was observed at both sites, in agreement with our source emissions measurement and supporting the suggestion that BB serves as an important primary source of HULIS in the atmosphere of PRD. In addition, good correlations were observed between HULIS and secondary species, such as sulfate and oxalate, at both sites. Significant correlation between HULIS and oxalate was also found in samples collected at an urban background site in Zurich, Switzerland (Samburova et al., 2005). Our previous studies (Yu et al., 2005; Huang et al., 2006) have demonstrated that in-cloud processing is the dominant formation pathway of sulfate and oxalate in the PRD region. The size distributions of HULIS measured at a rural 
Table 2. Correlation coefficient $(R)$ matrix among HULIS and the measured major constituents in $\mathrm{PM}_{2.5}$ at (a) the suburban site and (b) the urban site.

\begin{tabular}{|c|c|c|c|c|c|c|c|c|c|c|}
\hline & HULIS & $\mathrm{SO}_{4}^{2-}$ & Oxalate & $\mathrm{NO}_{3}^{-}$ & $\mathrm{NH}_{4}^{+}$ & $\mathrm{K}^{+}$ & $\mathrm{EC}$ & $\mathrm{Cl}^{-}$ & $\mathrm{Na}^{+}$ & $\mathrm{Mg}^{2+}$ \\
\hline \multicolumn{11}{|c|}{ (a) Suburban site } \\
\hline $\mathrm{SO}_{4}^{2-}$ & 0.807 & & & & & & & & & \\
\hline Oxalate & 0.826 & 0.883 & & & & & & & & \\
\hline $\mathrm{NO}_{3}^{-}$ & 0.700 & 0.639 & 0.773 & & & & & & & \\
\hline $\mathrm{NH}_{4}^{+}$ & 0.766 & 0.835 & 0.801 & 0.846 & & & & & & \\
\hline $\mathrm{K}^{+}{ }^{4}$ & 0.816 & 0.792 & 0.726 & 0.768 & 0.929 & & & & & \\
\hline $\mathrm{EC}$ & 0.624 & 0.567 & 0.613 & 0.598 & 0.608 & 0.650 & & & & \\
\hline $\mathrm{Cl}^{-}$ & 0.551 & 0.495 & 0.549 & 0.755 & 0.689 & 0.746 & 0.739 & & & \\
\hline $\mathrm{Na}^{+}$ & 0.423 & 0.464 & 0.557 & 0.683 & 0.690 & 0.667 & 0.543 & 0.716 & & \\
\hline $\mathrm{Mg}^{2+}$ & 0.011 & 0.118 & 0.022 & -0.015 & 0.063 & 0.069 & 0.103 & 0.174 & 0.053 & \\
\hline $\mathrm{Ca}^{2+}$ & 0.591 & 0.497 & 0.353 & 0.370 & 0.524 & 0.708 & 0.297 & 0.401 & 0.388 & 0.128 \\
\hline \multicolumn{11}{|c|}{ (b) Urban site } \\
\hline $\mathrm{SO}_{4}^{2-}$ & 0.772 & & & & & & & & & \\
\hline Oxalate & 0.933 & 0.834 & & & & & & & & \\
\hline $\mathrm{NO}_{3}^{-}$ & 0.620 & 0.528 & 0.691 & & & & & & & \\
\hline $\mathrm{NH}_{4}^{+}$ & 0.718 & 0.940 & 0.792 & 0.641 & & & & & & \\
\hline $\mathrm{K}^{+}{ }^{4}$ & 0.874 & 0.862 & 0.838 & 0.566 & 0.880 & & & & & \\
\hline EC & -0.056 & -0.051 & -0.005 & 0.092 & -0.045 & -0.025 & & & & \\
\hline $\mathrm{Cl}^{-}$ & 0.063 & 0.134 & 0.195 & 0.420 & 0.184 & 0.040 & 0.104 & & & \\
\hline $\mathrm{Na}^{+}$ & -0.012 & 0.032 & 0.010 & 0.047 & 0.043 & -0.040 & 0.070 & 0.710 & & \\
\hline $\mathrm{Mg}^{2+}$ & 0.116 & 0.150 & 0.151 & 0.221 & 0.152 & 0.199 & -0.031 & 0.548 & 0.810 & \\
\hline $\mathrm{Ca}^{2+}$ & 0.403 & 0.385 & 0.343 & 0.247 & 0.350 & 0.497 & 0.158 & 0.076 & 0.218 & 0.600 \\
\hline
\end{tabular}

site in the PRD region were also characterized by a dominant droplet mode, similar to those of sulfate and oxalate (Lin et al., 2010). These results strongly suggest that in-cloud processing could be a significant formation pathway of atmospheric HULIS in the PRD. A number of laboratory studies showed that certain atmospheric organic compounds were oxidized in simulated cloud water to high molecular weight compounds that displayed similar properties to HULIS (Gelencser et al., 2003; Hoffer et al., 2004; Holmes and Petrucci, 2006, 2007; Altieri et al., 2008). These laboratory experiments provided supporting evidence for secondary formation of HULIS through aqueous-phase oxidation.

$\mathrm{K}^{+}$had moderate correlation with EC at the suburban site while no correlation was found between the two species at the urban site. This is a logical result of different EC sources at the two sites. EC at the urban site was dominated by vehicle emissions while at the suburban site, a significant part of EC was contributed by biomass burning. Poor correlation between HULIS and EC was found at the urban site, consistent with the suggestion discussed in the previous section that primary emissions from vehicles were not an important source of HULIS in the urban area. However, it is worth noting that VOC emissions (e.g., toluene, xylenes) and semi-volatile aromatics from vehicles could have significant contributions to the precursor pool for the secondary formation of HULIS. The moderate correlation between HULIS and EC at the suburban site was likely due to BB being a common significant source of the two.

HULIS did not correlate with $\mathrm{Na}^{+}, \mathrm{Cl}^{-}$, or $\mathrm{Mg}^{2+}$ at the urban site, which is also located close to the coastal line. This result suggests that bubble-bursting on the ocean surface, proposed to be one of the HULIS sources in a remote coastal region (Cavalli et al., 2004), was trivial in its contribution in comparison with other possible HULIS sources in the PRD region. Poor correlation between HULIS and $\mathrm{Mg}^{2+}$, but moderate correlation of HULIS with $\mathrm{Na}^{+}$and $\mathrm{Cl}^{-}$were found at the suburban site. This is likely because $\mathrm{Na}^{+}$and $\mathrm{Cl}^{-}$in fine particles at the suburban site also have BB origin while the sea salt source was weaker due to its longer distance from the coast. Consequently, it is not surprising that the correlations of $\mathrm{Na}^{+}$with $\mathrm{Mg}^{2+}$ and $\mathrm{Cl}^{-}$with $\mathrm{Mg}^{2+}$ were poor at the suburban site. At the urban site, which was less influenced by the regional $\mathrm{BB}$ activities, the correlations among $\mathrm{Na}^{+}, \mathrm{Cl}^{-}$, and $\mathrm{Mg}^{2+}$ were substantially better.

It is noteworthy that HULIS correlated significantly with $\mathrm{O}_{3}$ and $\left(\mathrm{O}_{3}+\mathrm{NO}_{2}\right)$ (Fig. 5). Considering titration between $\mathrm{NO}$ and ozone in the urban area, the sum of ozone and $\mathrm{NO}_{2}$ concentrations better represents the gas-phase oxidant 

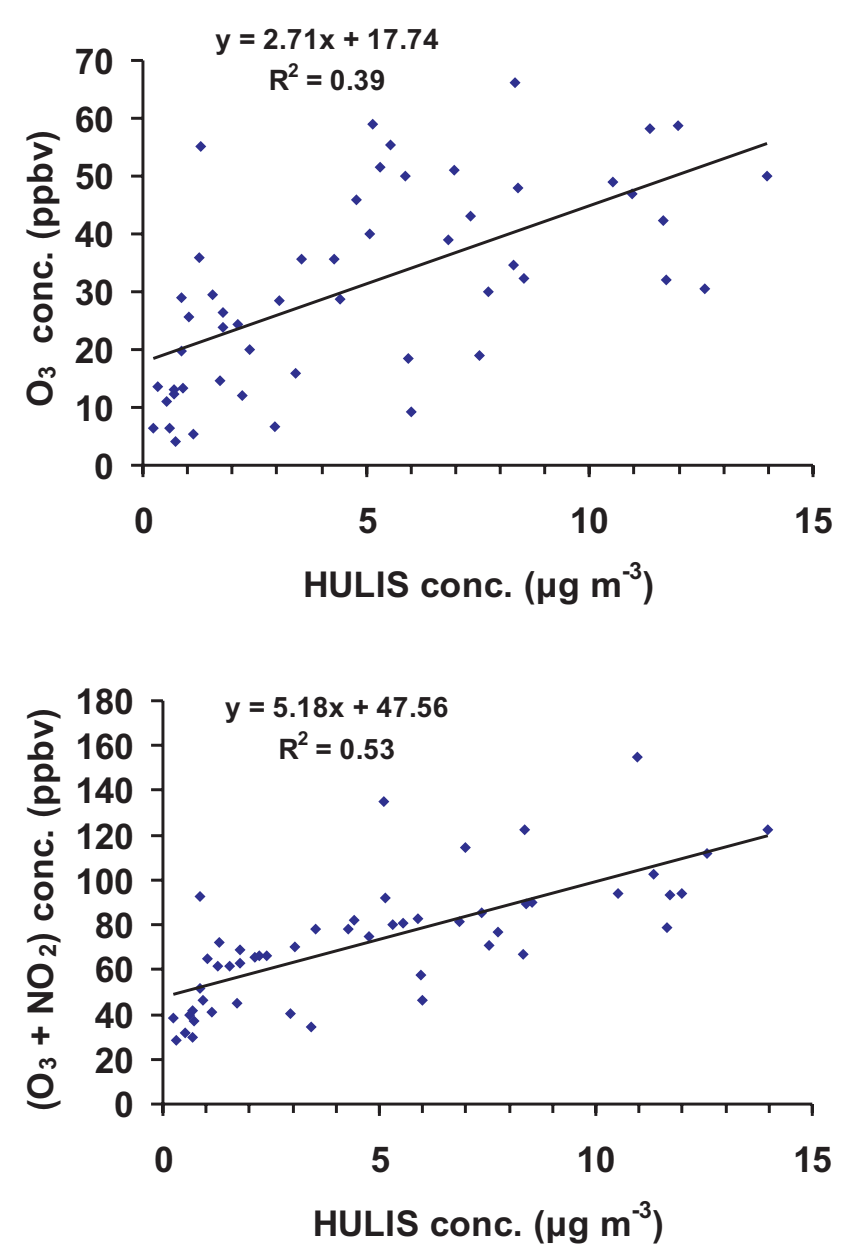

Fig. 5. Correlations between HULIS concentrations and ozone (top) and $\left(\mathrm{O}_{3}+\mathrm{NO}_{2}\right)$ concentrations (bottom) measured at the urban site.

level, which likely explains the improved correlation between HULIS and $\left(\mathrm{O}_{3}+\mathrm{NO}_{2}\right)\left(R^{2}=0.53\right)$ over that between HULIS and $\mathrm{O}_{3}\left(R^{2}=0.39\right)$ (Fig. 5). HULIS measurements at an urban background site in Europe also showed that the maximum molecular weight of the HULIS fractions positively correlated $\left(R^{2}=0.52\right)$ with ozone (Samburova et al., 2005). Similar analysis was carried out previously on secondary organic aerosol (SOA) derived from Aerosol Mass Spectrometry measurements in Mexico City and SOA was found to highly correlate with odd oxygen $\left(R^{2}>0.9\right)$ (Herndon et al., 2008). These results suggest that HULIS formation in the atmosphere is favored by increased photochemical activities, providing additional evidence for the secondary formation of HULIS in the atmosphere.

\section{Conclusions}

In this study, the concentrations of HULIS in fresh emissions of rice straw burning and in ambient aerosols sampled at an urban site and a suburban site in the Pearl River Delta, South China were determined. The main findings are:

(1) The HULIS/OC ratio in fresh rice straw burning smoke was $0.34 \pm 0.05 \mu \mathrm{g} / \mu \mathrm{gC}$, showing small variance among emissions under different field and chamber burning conditions. Similar HULIS/OC ratios $(\sim 0.3)$ were also measured in emissions from sugar cane and charcoal burning.

(2) The HULIS/OC ratios were significantly higher in ambient aerosols influenced by biomass burning, reaching $\sim 0.6$ in samples collected in the PRD and $\sim 1.0$ in three samples collected at a mountain top location in Taiwan when long-range transport of biomass burning aerosols occurred. These findings suggest that secondary formation of HULIS involving biomass burning particles or gaseous components is likely a significant source of HULIS.

(3) HULIS was abundant in ambient aerosols in the PRD region, accounting for $\sim 10 \%$ of $\mathrm{PM}_{2.5}$ mass. The annual average of HULIS at the suburban site was $7.1 \mu \mathrm{g}$ $\mathrm{m}^{-3}, 45 \%$ higher than that at the urban site $(4.9 \mu \mathrm{g}$ $\mathrm{m}^{-3}$ ). The urban-suburban spatial gradient of HULIS was opposite to that of elemental carbon, implying that vehicular exhaust was not a significant primary emission source of HULIS. On the other land, strong correlations of HULIS with biomass burning tracer $\mathrm{K}^{+}$, sulfate, oxalate, and oxidant in the ambient samples suggest that biomass burning and secondary formation are two significant sources of HULIS in the PRD region. Additional investigations regarding these two source types are necessary to further improve understanding of HULIS characteristics in this region.

\section{Supplementary material related to this article is available online at: http://www.atmos-chem-phys.net/10/6487/2010/ acp-10-6487-2010-supplement.pdf.}

Acknowledgements. This study was partially supported by the Research Grants Council of Hong Kong (621507). We gratefully acknowledge the Fok Ying Tung Foundation for funding to the Atmospheric Research Center (ARC) at HKUST Fok Ying Tung Graduate School, enabling sample collection at Nansha, and the Joint Fire Science Program in the US for making possible the collection of the laboratory burn samples. We thank the sampling and analysis team at ARC for sample collection and analysis of aerosol major constituents and HKEPD for making available air quality monitoring data at Tsuen Wan. Furthermore, we are thankful to George (N.H.) Lin from National Central University 
for use of the LABS site. We also thank American Association for Aerosol Research for partially supporting the publication cost.

Edited by: A. Chen

\section{References}

Allen, A. G. and Miguel A. H.: Biomass burning in the Amazon: Characterization of the ionic component of aerosols generated from flaming and smoldering rainforest and Savannah, Environ. Sci. Technol., 29, 486-493, 1995.

Altieri, K. E., Seitzinger, S. P., Carlton, A. G., et al.: Oligomers formed through in-cloud methylglyoxal reactions: Chemical composition, properties, and mechanisms investigated by ultrahigh resolution FT-ICR mass spectrometry. Atmos. Environ. 42, 1476-1490, 2008

Altieri, K. E., Turpin, B. J., and Seitzinger, S. P.: Oligomers, organosulfates, and nitrooxy organosulfates in rainwater identified by ultra-high resolution electrospray ionization FTICR mass spectrometry, Atmos. Chem. Phys., 9, 2533-2542, doi:10.5194/acp-9-2533-2009, 2009a.

Altieri, K. E., Turpin, B. J., and Seitzinger, S. P.: Composition of dissolved organic nitrogen in continental precipitation investigated by ultra-high resolution FT-ICR mass spectrometry, Environ. Sci. Technol., 43, 6950-6955, 2009b.

Andreae, M. O. and Merlet, P.: Emission of trace gases and aerosols from biomass burning, Global Biogeochem. Cy., 15(4), 955-966, 2001.

Bey, I., Jacob, D. J., Logan, J. A., and Yantosca, R. M.: Asian chemical outflow to the pacific in spring: Origins, pathways, and budgets, J. Geophys. Res., 116(D19), 23097-23113, 2001.

Baduel, C., Voisin, D., and Jaffrezo, J. L.: Comparison of analytical methods for Humic Like Substances (HULIS) measurements in atmospheric particles, Atmos. Chem. Phys., 9, 5949-5962, doi:10.5194/acp-9-5949-2009, 2009.

Cavalli, F., Facchini, M. C., Decesari, S., Mircea, M., Emblico, L., Fuzzi, S., Ceburnis, D., Yoon, Y. J., O’Dowd, C. D., Putaud, J.-P., and Dell'Acqua, A.: Advances in characterization of size-resolved organic matter in marine aerosol over the North Atlantic, J. Geophys. Res., 109, D24215, doi:10.1029/2004JD005137, 2004.

Chan, C. Y., Chan, L. Y., Zheng, Y. G., Harris, J. M., Oltmans, S. J., and Christopher, S.: Effects of 1997 Indonesian forest fires on tropospheric ozone enhancement, radiative forcing, and temperature change over the Hong Kong region, J. Geophys. Res., 106, 14875-14885, 2001.

Chen, X. and Yu, J. Z.: Measurement of organic mass to organic carbon ratio in ambient aerosol samples using a gravimetric technique in combination with chemical analysis, Atmos. Environ., 42, 8857-8864, 2007.

Chi, K. H., Lin, C. Y., Yang, C. F. O., Wang, J. L., Lin, N. H., Sheu, G. R., and Lee, C. T.: PCDD/F measurement at a high-altitude station in Central Taiwan: Evaluation of long-range transport of PCDD/Fs during the Southeast Asia biomass burning event, Environ. Sci. Technol., 44, 2954-2960, 2010.

Decesari, S., Facchini, M. C., Fuzzi, S., and Tagliavini, E.: Characterization of water-soluble organic compounds in atmospheric aerosol: A new approach, J. Geophys. Res., 105, 1481-1489, 2000 .
Dinar, E., Taraniuk, I., Graber, E. R., Katsman, S., Moise, T., Anttila, T., Mentel, T. F., and Rudich, Y.: Cloud Condensation Nuclei properties of model and atmospheric HULIS, Atmos. Chem. Phys., 6, 2465-2482, doi:10.5194/acp-6-2465-2006, 2006.

Duarte, R., Santos, E., Pio, C. A., and Duarte, A. C.: Comparison of structural features of water-soluble organic matter from atmospheric aerosols with those of aquatic humic substances, Atmos. Environ., 41, 8100-8113, 2007.

D’Anna, B., Jammoul, A., George, C., Stemmler, K., Fahrni, S., Ammann, M., and Wisthaler, A.: Light-induced ozone depletion by humic acid films and submicron aerosol particles, J. Geophys. Res., 114, D12301, doi:10.1029/2008JD001237, 2009.

Echalar, F., Gaudichet, A., Cachier, H., and Artaxo P.: Aerosol emissions by tropical forest and savanna biomass burning: Characteristic trace elements and fluxes, Geophys. Res. Lett., 22(22), 3039-3042, 1995.

Engling, G., Lee, J. J., Tsai, Y. W., Lung, S. C., Chou, C C.-K., and Chan C. Y.: Size-resolved anhydrosugar composition in smoke aerosol from controlled field burning of rice straw, Aerosol Sci. Technol., 43, 662-672, 2009.

Emmenegger, C., Reinhardt, A., Hueglin, C., Zenobi, R., and Kalberer, M.: Evaporative light scattering: A novel detection method for the quantitative analysis of humic-like substances in aerosols, Environ. Sci. Technol., 41, 2473-2478, 2007.

Feczko, T., Puxbaum, H., Kasper-Giebl, A., Handler, M., Limbeck, A., Gelencser, A., Pio, C., Preunkert, S., and Legrand, M.: Determination of water and alkaline extractable atmospheric humiclike substances with the TU Vienna HULIS analyzer in samples from six background sites in Europe, J. Geophys. Res., 112, D23S10, doi:10.1029/2006JD008331, 2007.

Fermo, P., Piazzalunga, A., Tuccillo, F., Brambilla, L., Cazzuli, O., Vecchi, R., and Valli, G.: Analytical methods for quantificantion and characterization of HULIS (HUmic Like Substances) in atmospheric aerosol, European Aerosol Conference 2009, Karlsruhe, Germany, 6-11 September 2009, Abstract T022A18, 2009.

Gao, S., Hegg, D. A., Hobbs, P. V., Kirchstetter, T. W., Magi, B. I., and Sadilek, M.: Water-soluble organic components in aerosols associated with savanna fires in southern Africa: Identification, evolution, and distribution, J. Geophys. Res., 108(D13), 8491, doi:10.1029/2002JD002324, 2003.

Gelencser, A., Hoffe, A., Kiss, G., Tombacz, E., Kurdi, R., and Bencze, L.: In-situ formation of light-absorbing organic matter in cloud water, J. Atmos. Chem., 45, 25-33, 2003.

Graber, E. R. and Rudich, Y.: Atmospheric HULIS: How humiclike are they? A comprehensive and critical review, Atmos. Chem. Phys., 6, 729-753, doi:10.5194/acp-6-729-2006, 2006.

Gysel, M., Weingartner, E., Nyeki, S., Paulsen, D., Baltensperger, U., Galambos, I., and Kiss, G.: Hygroscopic properties of water-soluble matter and humic-like organics in atmospheric fine aerosol, Atmos. Chem. Phys., 4, 35-50, doi:10.5194/acp-4-352004, 2004.

Hagler, G. S. W., Bergin, M. H., Salmon, L. G., Yu, J. Z., Wan, E. C. H., Zheng, M., Zeng, L. M., Kiang, C. S., Zhang, Y. H., Lau, A. K. H., and Schauer, J. J.: Source areas and chemical composition of fine particulate matter in the Pearl River Delta region of China, Atmos. Environ., 40, 3802-3815, 2006.

Havers, N., Burba, P., Lambert, J., and Klockow, D.: Spectroscopic 
characterization of humic-like substances in airborne particulate matter, J. Atmos. Chem., 29, 45-54, 1998a.

Havers, N., Burba, P., Klockow, D., and Klockow-Beck, A.: Characterization of humic-like substances in airborne particulate matter by capillary electrophoresis, Chromatographia, 47,619-624, 1998 b

Hays, M. D., Fine, P. M., Geron, C. D., Kleeman, M. J., and Gullett, B. K.: Open burning of agricultural biomass: Physical and chemical properties of particle-phase emissions, Atmos. Environ., 39, 6747-6764, 2005.

Herndon, S. C., Onasch,T. B., Wood, E. C., Kroll, J. H., Canagaratna,1M. R., Jayne, J. T., Zavala, M. A., Knighton, W. B., Mazzoleni, C., Dubey, M. K., Ulbrich, I. M., Jimenez, J. L., Seila, R., de Gouw,J. A., de Foy, B., Fast, J., Molina, L. T., Kolb, C. E., and Worsnop, D. R.: Correlation of secondary organic aerosol with odd oxygen in Mexico City, Geophys. Res. Lett., 35, L15804, doi:10.1029/2008GL034058, 2008.

Hobbs, P. V., Sinha, P., Yokelson, R. J., Christian, T. J., Blake, D. R., Gao, S., Krichstetter, T. W., Novakov, T., and Pilewskie, P.: Evolution of gases and particles from a savanna fire in South Africa, J. Geophys. Res., 108(D13), 8485, doi:10.1029/2002JD002352, 2003.

Hoffer, A., Kiss, G., Blazsó, M., and Gelencsér, A.: Chemical characterization of humic-like substances (HULIS) formed from a lignin-type precursor in model cloud water, Geophys. Res. Lett., 31, L06115, doi:10.1029/2003GL018962, 2004.

Hoffer, A., Gelencsér, A., Guyon, P., Kiss, G., Schmid, O., Frank, G. P., Artaxo, P., and Andreae, M. O.: Optical properties of humic-like substances (HULIS) in biomass-burning aerosols, Atmos. Chem. Phys., 6, 3563-3570, doi:10.5194/acp-6-3563-2006, 2006.

Holmes, B. J. and Petrucci, G. A.: Water-soluble oligomer formation from acid-catalyzed reactions of levoglucosan in proxies of atmospheric aqueous aerosols, Environ. Sci. Technol., 40, 49834989, 2006.

Holmes, B. J. and Petrucci, G. A.: Oligomerization of levoglucosan by Fenton chemistry in proxies of biomass burning aerosols, J. Atmos. Chem., 58, 151-166, 2007.

Huang, X. F., Yu, J. Z., He, L. Y., and Yuan, Z.: Watersoluble organic carbon and oxalate in aerosols at a coastal urban site in China: Size distribution characteristics, sources, and formation mechanisms, J. Geophys. Res., 111, D22212, doi:10.1029/2006JD007408, 2006.

Hutta, M. and Gora, R.: Novel stepwise gradient reversed-phase liquid chromatography separations of humic substances, air particulate humic-like substances, and lignins, J. Chromatogr. A, 1012, 67-79, 2003.

Jang, M. S., Czoschke, N. M., Lee, S., and Kamens, R. M.: Heterogeneous atmospheric aerosol production by acid-catalyzed particle-phase reactions, Science, 298, 814-817, 2002.

Jang, M. S., Carroll, B., Chandramouli, B., and Kamens, R. M.: Particle growth by acid-catalyzed heterogeneous reactions of organic carbonyls on preexisting aerosols, Environ. Sci. Technol., 37, 3828-3837, 2003.

Kalberer, M., Paulsen, D., Sax, M., Steinbacher, M., Dommen, J., Prevot, A. S. H., Fisseha, R., Weingartner, E., Frankevich, V., Zenobi, R., and Baltensperger, U.: Identification of polymers as major components of atmospheric organic aerosols, Science, 303, 1659-1662, 2004.
Khalil, M. A. K. and Rasmussen, R. A.: Tracers of wood smoke, Atmos. Environ., 37, 1211-1222, 2003.

Kiss, G., Varga, B., Galambos, I., and Ganszky, I.: Characterization of water-soluble organic matter isolated from atmospheric fine aerosol, J. Geophys. Res., 107(D21), 8339, doi:10.1029/2001JD000603, 2002.

Krivacsy, Z., Kiss, G., Varga, B., Galambos, I., Sarvari, Z., Gelencser, A., Molnar, A., Fuzzi, S., Facchini, M. C., Zappoli, S., Andracchio, A., Alsberg, T., Hansson, H. C., and Persson, L.: Study of humic-like substances in fog and interstitial aerosol by size exclusion chromatography and capillary electrophoresis, Atmos. Environ., 34, 4273-4281, 2000.

Krivácsy, Z., Kiss, G., Ceburnis, D., Jennings, G., Maenhaut, W., Salma, I., and Shooter, D.: Study of water-soluble atmospheric humic matter in urban and marine environments, Atmos. Res., 87, 1-12, 2008.

Lee, C. T., Lin, N. H., Hou, Y. H., and Chang, S. Y.: Humic-like substances in the transported biomass burning plume at Mt. Lulin in Taiwan, European Aerosol Conference 2009, Karlsruhe, Germany, 6-11 September 2009, Abstract T057A08, 2009.

Lemieux, P. M., Lutes, C. C., and Santoianni, D. A.: Emissions of organic air toxics from open burning: a comprehensive review, Prog. Energ. Combust., 30, 1-32, 2004.

Limbeck, A., Handler, M., Neuberger, B., Klatzer, B., and Puxbaum, H.: Carbon-specific analysis of humic-like substances in atmospheric aerosol and precipitation samples, Anal. Chem., 77, 7288-7293, 2005

Lin, P., Huang, X. F., He, L. Y., and Yu, J. Z.: Abundances and size distribution of HULIS in ambient aerosols at a rural site in South China, J. Aerosol Sci., 41, 74-87, doi:10.1016/j.jaerosci.2009.09.001, 2010.

Lukács, H., Gelencser, A., Hammer, S., Puxbaum, H., Pio, C., Legrand, M., Kasper-Giebl, A., Handler, M., Limbeck, A., Simpson, D., and Preunker, S.: Seasonal trends and possible sources of brown carbon based on 2-year aerosol measurements at six sites in Europe, J. Geophys. Res., 112, D23S18, doi:10.1029/2006JD008151, 2007.

Marion, T., Perros, P. E., Losno, R., and Steiner, E.: Ozone production in savanna and forested areas during the EXPRESSO experiment, J. Atmos. Chem., 38, 3-30, 2001.

Mayol-Bracero, O. L., Guyon, P., Graham, B., Roberts, G., Andreae, M. O., Decesari, S., Facchini, M. C., Fuzzi, S., and Artaxo, P.: Water-soluble organic compounds in biomass burning aerosols over Amazonia, 2, Apportionment of the chemical composition and importance of the polyacidic fraction, J. Geophys. Res., 107(D20), 8091, doi:10.1029/2001JD000522, 2002.

Mazzoleni L. R., Zielinska B., and Moosmüller H.: Emissions of Levoglucosan, Methoxy Phenols, and Organic Acids from Prescribed Burns, Laboratory Combustion of Wildland Fuels, and Residential Wood Combustion, Environ. Sci. Technol., 41, 2115-2122, 2007.

Mazzoleni, L. R., Ehrmann, B. M., Shen, X. H., Marshall, A. G., and Collett, J. L.: Water-soluble atmospheric organic matter in fog: exact masses and chemical formula identification by ultrahigh-resolution Fourier transform ion cyclotron resonance mass spectrometry, Environ. Sci. Technol., 44, 3690-3697, 2010.

McKeen, S. A., Wotawa, G., Parrish, D. D., Holloway, J. S., Buhr, M. P., Hubler, G., Fehsenfeld, F. C., and Maegher, J. F.: Ozone production from Canadian wildfires during 
June and July of 1995, J. Geophys. Res., 107(D14), 4192, doi:10.1029/2001JD000697, 2002.

McMeeking, G. R., Kreidenweis, S. M., Baker, S., Carrico, C. M., Chow, J. C., Collett Jr., J. L., Hao, W. M., Holden, A. S., Kirchstetter, T. W., Malm, W. C., Moosmuller, H., Sullivan, A. P., and Wold, C. E.: Emissions of trace gases and aerosols during the open combustion of biomass in the laboratory, J. Geophys. Res., 114, D19210, doi:10.1029/2009JD011836, 2009.

Moonshine, M., Rudich, Y., Katsman, S., and Graber, E. R., Atmospheric HULIS enhance pollutant degradation by promoting the dark Fenton reaction, Geophys. Res. Lett., 35, L20807, doi:10.1029/2008GL035285, 2008.

Mukai, H. and Ambe, Y., Characterization of a humic acid-like brown substance in airborne particulate matter and tentative identification of its origin, Atmos. Environ., 20, 813-819, 1986.

Nguyen, B., Mihalopoulos, N., and Putaud, J.-P.: Rice straw burning in Southeast Asia as a source of CO and COS to the atmosphere, J. Geophys. Res., 99, 16435-16439, 1994.

Reemtsma, T., These, A., Venkatachari, P., Xia, X., Hopke, P. K., Springer, A., and Linscheid, M.: Identification of fulvic acids and sulfated and nitrated analogues in atmospheric aerosol by electrospray ionization Fourier transform ion cyclotron resonance mass spectrometry, Anal. Chem., 78, 8299-8304, 2006.

Rogers, F. C., Hudson, J. G., Zielinska, B., Tanner, R. L., Hallett, J., and Watson, J. G.: Cloud condensation nuclei from Biomass Burning, in: Global Biomass Burning: Atmospheric, Climatic and Biospheric Implications, edited by: Levine, J. S., MIT Press, Cambridge, England, 431-438, 1991.

Salma, I., Mészáros, T., Maenhaut, W., Vass, E., and Majer, Z.: Chirality and the origin of atmospheric humic-like substances, Atmos. Chem. Phys., 10, 1315-1327, doi:10.5194/acp-10-13152010, 2010.

Samburova, V., Szidat, S., Hueglin, C., Fisseha, R., Baltensperger, U., Zenobi, R., and Kalberer, M.: Seasonal variation of high-molecular-weight compounds in the water-soluble fraction of organic urban aerosols, J. Geophys. Res., 110, D23210, doi:10.1029/2005JD005910, 2005.

Sannigrahi, P., Sullivan, A. P., Weber, R. J., and Ingall, E. D.: Characterization of Water-Soluble Organic Carbon in Urban Atmospheric Aerosols Using Solid-State ${ }^{13}$ C NMR Spectroscopy, Environ. Sci. Technol., 40, 666-672, 2006.

Sheu, G. R., Lin, N. H., Wang, J. L., Lee, C. T., Yang, C. F. O., and Wang, S. H.: Temporal distribution and potential sources of atmosphetic mercury measured at a high-elevation background station in Taiwan, Atmos. Environ., 44, 2393-2400, 2010.

Simoneit, B. R. T.: Biomass burning-a review of organic tracers for smoke from incomplete combustion, Appl. Geochem., 17, 129162,2002

Streets, D. G., Yarber, K. F., Woo, J. H., and Carmichael, G. R.: Biomass burning in Asia: annual and seasonal estimates and atmospheric emissions, Global Biogeochem. Cy., 17(4), 1099, doi:10.1029/2003GB002040, 2003.
Thompson, A. M., Witte, J. C., Hudson, R. D., Guo, H., Herman, J. R., and Fujiwara, M.: Tropical tropospheric ozone and biomass burning, Science, 291, 2128-2132, 2001.

Varga, B., Kiss, G., Ganszky, I., Gelencser, A., and Krivacsy, Z.: Isolation of water-soluble organic matter from atmospheric aerosol, Talanta, 55, 561-572, 2001.

Wai, K. M., Lin, N.-H., Wang, S.-H., and Dokiya, Y.: Rainwater chemistry at a high-altitude station, Mt. Lulin, Taiwan: Comparison with a background station, Mt. Fuji, J. Geophys. Res., 113, D06305, doi:10.1029/2006JD008248, 2008.

Wan, E. C. H. and Yu, J. Z.: Analysis of sugars and sugar polyols in atmospheric aerosols by chloride attachment in liquid chromatography / negative ion electrospray mass spectrometry, Environ. Sci. Technol., 41(7), 2459-2466, 2007.

Wozniak, A. S., Bauer, J. E., Sleighter, R. L., Dickhut, R. M., and Hatcher, P. G.: Technical Note: Molecular characterization of aerosol-derived water soluble organic carbon using ultrahigh resolution electrospray ionization Fourier transform ion cyclotron resonance mass spectrometry, Atmos. Chem. Phys., 8, 50995111, doi:10.5194/acp-8-5099-2008, 2008.

Yang, H., Yu, J. Z., Ho, S. S. H., Xu, J., Wu, W. S., Wan, C. H., Wang, X. D., Wang, X. R., and Wang L. S.: The chemical composition of inorganic and carbonaceous materials in $\mathrm{PM}_{2.5}$ in Nanjing, China, Atmos. Environ., 39, 3735-3749, 2005.

Yu, J. Z., Tung, J. W. T., Wu, A. W. M., Lau, A. K. H., Louie, P. K. K., and Fung, J. C. H.: Abundance and seasonal characteristics of elemental and organic carbon in Hong Kong $\mathrm{PM}_{10}$, Atmos. Environ., 38, 1511-1521, 2004a.

Yu, J. Z., Yang, H., Zhang, H. Y., and Lau, A. K. H.: Size distributions of water-soluble organic carbon in ambient aerosols and its size-resolved thermal characteristics, Atmos. Environ., 38, 1061-1071, 2004b.

Yu, J. Z., Huang, X. F., Xu, J. H., and Hu, M.: When aerosol sulfate goes up, so does oxalate: Implication for the formation mechanism of oxalate, Environ. Sci. Technol., 39, 128-133, 2005.

Yuan, Z. B., Lau, A. K. H.,Zhang, H. Y., Yu, J. Z., Louie, P. K. K., and Fung, J. C. H.: Identification and spatial distribution of dominant sources of $\mathrm{PM}_{10}$ in Hong Kong, Atmos. Environ, 40, 1803-1815, 2006.

Zappoli, S., Andracchio, A., Fuzzi, S., Facchini, M. C., Gelencser, A., Kiss, G., Krivacsy, Z., Molnar, A., Meszaros, E., Hansson,H. C., Rosman, K., and Zebuhr, Y.: Inorganic, organic and macromolecular components of fine aerosol in different areas of Europe in relation to their water solubility, Atmos. Environ., 33, 2733 2743, 1999.

Zheng, M., Hagler, G. S. W., Ke, L., Bergin, M. H., Wang, F., Louie, P. K. K., Salmon, L., Sin, D. W. M., Yu, J. Z., and Schauer, J. J.: Composition and sources of carbonaceous aerosols at three contrasting sites in Hong Kong, J. Geophys. Res., 111, D20313, doi:10.1029/2006JD007074, 2006. 